\title{
An evaluation of the anti-inflammatory effect of flurbiprofen after cataract extraction
}

\author{
D W SABISTON, AND I G ROBINSON* \\ From the Napier Public Hospital, Napier, New Zealand
}

SUMMARY Thirty-eight patients requiring cataract extraction were randomly assigned to receive either flurbiprofen $100 \mathrm{mg}$ twice daily in addition to routine postoperative therapy or the routine therapy alone. The trial was single blind with clinical assessments at postoperative days $1,3,7,14$, and 28. All measures of inflammatory response were significantly less in the group of patients receiving flurbiprofen, and in most cases the clinician's assessment as to which group each patient belonged to was correct. This trial suggests that flurbiprofen reduces inflammatory response in the eye in the first few days following cataract extraction and may therefore reduce the risk of severe and potentially disastrous reactions which sometimes occur.

It is to be expected that after cataract extraction patients will develop some symptoms of ocular inflammation. Traditionally this is treated with local steroid drops, and if it becomes severe systemic steroids may be used. ${ }^{2}$ There are numerous well documented hazards associated with steroid therapy, but it is imperative that, when an eye does react badly to surgery, the inflammatory process be kept to a minimum, thus reducing the amount of damage to extra and intraocular tissues, particularly the latter. Intraocular tissues involved in any severe inflammatory process quickly lose their vitality, with subsequent loss of functions. This can be irreversible with permanent visual loss.

Flurbiprofen is a propionic acid derivative with potent analgesic, antipyretic, and anti-inflammatory properties.$^{34}$ It is rapidly absorbed after oral administration, giving peak serum concentrations within approximately one and a half hours. The drug does not accumulate to any marked extent on repeat dosing. Many clinical trials have established the efficacy of flurbiprofen in rheumatic and associated conditions, and its safety has been established in controlled long-term studies. ${ }^{56}$ Wide clinical usage has confirmed these findings over several years. ${ }^{7 \cdot 10}$

This trial reports the effect of giving flurbiprofen for the reduction of postoperative ocular inflammation.

Correspondence to D W Sabiston, FRCS. PO Box 294. Napier, New Zealand.

* Medical Dircctor, Australia and South East Asia, Boots Company (Australia) Pty Ltd.

\section{Material and methods}

The protocol required that 40 patients of any age and either sex who needed cataract extraction, and had given informed, written consent, be admitted to the study. The cataracts were removed intracapsularly without intraocular lens implantation by a microsurgical technique using cryoextraction and by a standardised technique for all patients. All patients were given $1 \%$ chloramphenicol ointment immediately the surgery was completed, and then $0.5 \%$ chloramphenicol drops four times daily for 10 days postoperatively. Aqueous samples were removed from 10 patients (Table 1 ).

Table 1 Preoperative levels of flurbiprofen in aqueous humour following an oral dose of $100 \mathrm{mg}$ three hours previously

\begin{tabular}{cc}
\hline $\begin{array}{c}\text { Patient Number } \\
\text { Receiving tablets orally }\end{array}$ & $\begin{array}{c}\text { Concentration furbiprofen } \\
\text { NG/ML aqueous humour }\end{array}$ \\
\hline T1 & 18 \\
T2 & 9 \\
T3 & 13 \\
T4 & $14 \cdot 5$ \\
T5 & 22 \\
T6 & 20 \\
T7-T10 & Volume submitted insufficient \\
& (less than $20 \mu \mathrm{l}$ ) \\
\hline
\end{tabular}

Number of patients: 6 . Mean concentration $16 \cdot 1 \mathrm{ng}$ flurbiprofen per ml aqueous humour (SD 4.8).

SI conversion: $\mathrm{ng} / \mathrm{ml}=\mu \mathrm{g} / \mathrm{l}$. 
The patients were admitted on a random basis to one of two groups, one of which received no additional routine therapy and the other flurbiprofen $100 \mathrm{mg}$ twice daily by mouth. The first dose of flurbiprofen was given three hours prior to the operation, and subsequent doses with breakfast and the evening meal for a period of 10 days. This study was single blind, so that if an eye deteriorated suddenly the clinician could immediately ascertain to which group the patient belonged and act accordingly. In normal circumstances, however, the clinician was not aware of which patients were receiving flurbiprofen. Patients with a known hypersensitivity to non-steroidal anti-inflammatory drugs (NSAIDs), or patients currently being treated with one of these preparations, were excluded.

Past medical and ocular history were recorded as well as the results of a detailed preoperative ocular examination. The trial began on the day of operation (day 0 ), and the results of clinical examinations were recorded on days $1,3,7,14$, and 28 . These examinations included the condition of the lids, conjunctiva, cornea, and anterior chamber plus any other observations the clinician considered worth recording. Each parameter was graded I to IV by the guidelines given in Table 2 .

Operative details and any complications were recorded on the evaluation sheet, as were severity of any side effects. At the end of the trial the investigating clinician recorded a summary of the patient's progress and also a blind assessment of whether each patient received flurbiprofen or not.

Table 2 Guidelines for assessing inflammatory response in various ocular tissues

\begin{tabular}{lllll}
\hline & Lids & Conjunctiva & Cornea & $\begin{array}{l}\text { Anterior } \\
\text { chamber }\end{array}$ \\
\hline $\begin{array}{l}\text { Grade I } \\
\text { Grade II }\end{array}$ & $\begin{array}{l}\text { Normal } \\
\text { Slightly red }\end{array}$ & $\begin{array}{l}\text { Normal } \\
\text { Slightly red }\end{array}$ & $\begin{array}{l}\text { Normal } \\
\text { Slight haze }\end{array}$ & $\begin{array}{l}\text { Normal } \\
\text { Slight } \\
\text { flare }\end{array}$ \\
Grade III & Red & Red & $\begin{array}{l}\text { Infiltrated } \\
\text { by cells } \\
\text { Cells and } \\
\text { corncal folds }\end{array}$ & $\begin{array}{l}\text { Flare and } \\
\text { cells }\end{array}$ \\
\hline
\end{tabular}

\section{Results}

The trial involved 38 cataract extractions, with patients being randomly assigned flurbiprofen 100 mg twice daily or to the control group where no NSAID was taken. One patient in each group had simultaneous bilateral operations, and the recorded results for only one eye have been included for each of these patients. Of the 38 patients who completed the investigation 20 were in the flurbiprofen group and 18 in the control group. The trial was single blind with the clinician not knowing to which group a patient belonged. The patients' ages ranged from 42 to 86 years and a two-sample $t$ test showed no significant difference between the groups. The flurbiprofen group consisted of six males and 14 females, and the control group seven males and 11 females. A $\chi^{2}$ test showed no significant differences between the groups.

The responses for the patients for each individual parameter were tested for significance by a $\chi^{2}$ test. These results are given in Tables 3 to 6 . The results indicate that the eyelids of patients taking flurbiprofen became less inflamed and swollen than in the control group. This tendency was shown after three days, and the difference is statistically significant at the first week. As would be expected, this difference disappeared by days 14 and 28 .

The condition of the eyelids was graded I to IV according to the amount of redness and swelling present. The results for the two groups at the various assessment times are given in Table 3 . The postoperative state of the conjunctiva was assessed clinically and graded I to IV according to redness present and thus the degree of inflammation. Table 4 gives the results for both groups of patients at each assessment day. The patients taking flurbiprofen showed less redness than the control group, and this is statistically significant at day 3 , though the latter group settled with time and the significance disappeared at later assessments.

The postoperative changes in the cornea were evaluated clinically at each assessment day and graded I to IV according to the degree of haze and

Table 3 Postoperative condition of eyelids

\begin{tabular}{|c|c|c|c|c|c|c|c|c|c|c|}
\hline \multirow{2}{*}{$\begin{array}{l}\text { Postoperative day: } \\
\text { Response }\end{array}$} & \multicolumn{2}{|l|}{1} & \multicolumn{2}{|l|}{3} & \multicolumn{2}{|l|}{7} & \multicolumn{2}{|l|}{14} & \multicolumn{2}{|l|}{28} \\
\hline & Flurb & Cont & Flurb & Cont & Flurb & Cont & Flurb & Cont & Flurb & Cont \\
\hline I & 10 & 7 & 13 & 6 & 16 & 6 & 15 & 12 & 17 & 15 \\
\hline II & 9 & 11 & 7 & 8 & 2 & 11 & 3 & 5 & () & 1 \\
\hline III (and IV) & 1 & 0 & 0 & 4 & 1 & () & () & () & () & () \\
\hline Total & 20 & 18 & 20 & 18 & 19 & 17 & 18 & 17 & 17 & 16 \\
\hline p value & \multicolumn{2}{|c|}{ NS } & \multicolumn{2}{|c|}{ NS } & \multicolumn{2}{|c|}{$<() \cdot() 1$} & \multicolumn{2}{|c|}{ NS } & \multicolumn{2}{|c|}{ NS } \\
\hline
\end{tabular}

Flurb = flurbiprofen. Cont $=$ control. 
Table 4 Postoperative conjunctival changes

\begin{tabular}{|c|c|c|c|c|c|c|c|c|c|c|}
\hline \multirow{2}{*}{$\begin{array}{l}\text { Postoperative day: } \\
\text { Response }\end{array}$} & \multicolumn{2}{|l|}{1} & \multicolumn{2}{|l|}{3} & \multicolumn{2}{|l|}{7} & \multicolumn{2}{|l|}{14} & \multicolumn{2}{|l|}{28} \\
\hline & Flurb & Cont & Flurb & Cont & Flurb & Cont & Flurb & Cont & Flurb & Cont \\
\hline I & 0 & 1 & 0 & 2 & 4 & 2 & 10 & 3 & 15 & 10 \\
\hline II & 18 & 15 & 19 & 8 & 12 & 13 & 7 & 13 & 2 & 6 \\
\hline III & 2 & 2 & 1 & 8 & 3 & 2 & 1 & 1 & 0 & 0 \\
\hline Total & 20 & 18 & 20 & 18 & 19 & 17 & 18 & 17 & 17 & 16 \\
\hline p value & \multicolumn{2}{|c|}{ NS } & \multicolumn{2}{|c|}{$<0 \cdot 01$} & \multicolumn{2}{|c|}{ NS } & \multicolumn{2}{|c|}{ NS } & \multicolumn{2}{|c|}{ NS } \\
\hline
\end{tabular}

Table 5 Postoperative condition of the corneas

\begin{tabular}{|c|c|c|c|c|c|c|c|c|c|c|}
\hline \multirow{2}{*}{$\begin{array}{l}\text { Postoperative day: } \\
\text { Response }\end{array}$} & \multicolumn{2}{|l|}{1} & \multicolumn{2}{|l|}{3} & \multicolumn{2}{|l|}{7} & \multicolumn{2}{|l|}{14} & \multicolumn{2}{|l|}{28} \\
\hline & Flurb & Cont & Flurb & Cont & Flurb & Cont & Flurb & Cont & Flurb & Cont \\
\hline I & 6 & 4 & 13 & 5 & 16 & 5 & 15 & 10 & 17 & 14 \\
\hline II & 13 & 10 & 5 & 6 & 1 & 9 & 2 & 7 & 0 & 2 \\
\hline III & 1 & 4 & 2 & 7 & 2 & 3 & 1 & 0 & 0 & 0 \\
\hline Total & 20 & 18 & 20 & 18 & 19 & 17 & 18 & 17 & 17 & 16 \\
\hline p value & \multicolumn{2}{|c|}{ NS } & \multicolumn{2}{|c|}{$<0.05$} & \multicolumn{2}{|c|}{$<0 \cdot 01$} & \multicolumn{2}{|c|}{ NS } & \multicolumn{2}{|c|}{ NS } \\
\hline
\end{tabular}

Table 6 Clinical condition of the anterior chambers

\begin{tabular}{|c|c|c|c|c|c|c|c|c|c|c|}
\hline \multirow{2}{*}{$\begin{array}{l}\text { Postoperative day: } \\
\text { Response }\end{array}$} & \multicolumn{2}{|l|}{1} & \multicolumn{2}{|l|}{3} & \multicolumn{2}{|l|}{7} & \multicolumn{2}{|l|}{14} & \multicolumn{2}{|l|}{28} \\
\hline & Flurb & Cont & Flurb & Cont & Flurb & Cont & Flurb & Cont & Flurb & Cont \\
\hline I & 6 & 3 & 13 & 4 & 16 & 5 & 14 & 11 & 17 & 15 \\
\hline II & 11 & 10 & 5 & 5 & 1 & 5 & 3 & 6 & 0 & 1 \\
\hline III & 3 & 5 & 2 & 4 & 2 & 7 & 1 & 0 & 0 & 0 \\
\hline IV & 0 & 0 & 0 & 5 & 0 & 0 & 0 & 0 & 0 & 0 \\
\hline Total & 20 & 18 & 20 & 18 & 19 & 17 & 18 & 17 & 17 & 16 \\
\hline p value & \multicolumn{2}{|c|}{ NS } & \multicolumn{2}{|c|}{$<0.05$} & \multicolumn{2}{|c|}{$<0.01$} & \multicolumn{2}{|c|}{ NS } & \multicolumn{2}{|c|}{ NS } \\
\hline
\end{tabular}

cells present. These findings are recorded in Table 5 . The patients taking flurbiprofen showed significantly less corneal reaction at day $3(\mathrm{p}<0.05)$ and day 7 $(\mathrm{p}<0.01)$ than the control group. As time progressed to days 14 and 28 the inflammatory reaction of the control group also settled, and as expected the significance levels again disappeared.

The postoperative condition of the anterior chamber was also assessed and, using the degree of flare and the presence of cells, graded I to IV. The results at each assessment day are given in Table 6 . These results show that patients taking flurbiprofen had less reaction in the anterior chamber than the control group and that this difference was statistically significant at day $3(p<0 \cdot 05)$ and day $7(p<0 \cdot 01)$. No patient in the flurbiprofen group was reported to have cells in the anterior chamber as compared with five reports in the control group.

These results indicate that in every parameter assessed there were significant advantages to the patients in the flurbiprofen group as compared with the controls. These advantages were most marked in
Table 7 Clinician's assessment of whether patient taking flurbiprofen

\begin{tabular}{|c|c|c|}
\hline Clinician's opinion & Flurbiprofen group & Control group \\
\hline On flurbiprofen & 17 & 4 \\
\hline Not on flurbiprofen & 2 & 13 \\
\hline Unsure & 1 & 1 \\
\hline Total & 20 & 18 \\
\hline
\end{tabular}

Table 8 Reasons for patients failing to complete the trial

Patient Age Sex Day of last Flurbiprofen Reason for withdrawal assessment

\begin{tabular}{|c|c|c|c|c|c|}
\hline 9 & 76 & $F$ & 7 & Yes & $\begin{array}{l}\text { Visual hallucinations } \\
\text { and confusion }\end{array}$ \\
\hline 15 & 75 & $F$ & 3 & Yes & $\begin{array}{l}\text { Abdominal pains and } \\
\text { vomiting }\end{array}$ \\
\hline 38 & 78 & $\mathbf{F}$ & 14 & Yes & $\begin{array}{l}\text { Late flare - topical } \\
\text { steroids }\end{array}$ \\
\hline 2 & 66 & $\mathbf{M}$ & 3 & No & $\begin{array}{l}\text { Allergic response to } \\
\text { chloramphenicol }\end{array}$ \\
\hline 24 & 85 & $\mathrm{~F}$ & 14 & No & Bad flare up \\
\hline
\end{tabular}


the first few postoperative days, as one would expect. This period is when the patient is most at risk from inflammation.

The clinician made an overall assessment on a blind basis to decide whether each individual patient had received flurbiprofen or not, and these results are given in Table 7. There was a strong relationship between the clinician's opinion and whether or not the patient was taking flurbiprofen; this is statistically significant $(p<0 \cdot 01)$. In the majority of cases it was clinically apparent that patients given flurbiprofen showed less inflammatory response than the control group.

Five patients failed to complete the study and these details are given in Table 8.

NSAIDs are known to cause gastric irritation in susceptible patients, and probably patient 15 had drug complications. There were no other withdrawals which seem likely to be drug related, nor were there any adverse effects reported in patients taking flurbiprofen. It should be noted that patient 38 was withdrawn on day 14 because of a late flare up which occurred four days after cessation of flurbiprofen. It is possible that continuing flurbiprofen for a few more days would have avoided this occurrence.

\section{Discussion}

In this single-blind study of the anti-inflammatory effect of flurbiprofen following cataract extraction it was clearly demonstrated that patients receiving the drug had much quieter eyes than those without NSAID. The development of ocular inflammation is usual after cataract extraction and can sometimes be very serious. The use of a potent anti-inflammatory agent such as flurbiprofen appears to reduce this risk without an unacceptable risk to the patient from side effects.

\section{References}

1 Burde RM, Waltman SR. Topical corticosteroids after cataract surgery. Ann Ophthalmol 1972; 4: 290-3.

2 Mustakallio A, Kaufman HE, Johnston G, Wilson RS, Roberts MD. Corticosteroids efficacy in postoperative uveitis. Ann Ophthalmol 1973; 6: 719-30.

3 Adams SS, Buckler JW. Ibuprofen and flurbiprofen. Clin Rheum Dis 1979; 5: 359-79.

4 Jaffe BM, Podos, SM, Becker B. Indomethacin blocks arachidonic acid-associated elevation of aqueous humor prostaglandin E. Invest Ophthalmol Vis Sci 1973; 12: 621-2.

5 Geiser DK, Hodapp E, Goldberg I, Kass MA, Becker B. Flurbiprofen and intraocular pressure. Ann Ophthalmol 1981; 13: 831-3.

6 Trousdal MD, Dunkel ED, Weburn AB. Effect of flurbiprofen on herpes simplex keratitis in rabbits. Invest Ophthalmol Vis Sci 1980; 19: 267-70.

7 Greave MW. Prostaglandins and inflammation. In: Karim SM, ed. Prostaglandins: physiological, pharmacological and pathological aspects. Baltimore: University Park Press. 1976: 293-302.

8 Podos SM. Prostaglandins, non-steroidal anti-inflammatory agents and eye disease. Trans Am Ophthalmol Soc 1977; 74: 637-60.

9 Miller D, Gruenberg P, Miller R, Bergamini MV. Topical flurbiprofen or prednisolone: effect on corneal wound healing on rabbits. Arch Ophthalmol 1981; 99: 681-2.

10 Weinreb RN, Robin AL, Baerveldt G, Drake MV, Blumenthal $M$, Wilensky J. Flurbiprofen pretreatment in argon laser trabeculoplasty for primary open-angle glaucoma. Arch Ophthalmol 1984; 102: 1629-32.

Accepted for publication 14 February 1986. 